\title{
USE OF ELECTROCONVULSIVE THERAPY IN CENTRAL-EASTERN EUROPEAN COUNTRIES: AN OVERVIEW
}

\author{
Gábor Gazdag $^{1,2}$, Jozef Dragasek ${ }^{3}$, Rozália Takács ${ }^{1}$, Margus Lõokene ${ }^{4}$, Tomasz Sobow $^{5}$, \\ Aleksey Olekseev $^{6}$ \& Gabor S. Ungvari ${ }^{7,8}$ \\ ${ }^{I}$ Centre for Psychiatry and Addiction Medicine, Szent István and Szent László Hospitals, Budapest, Hungary \\ ${ }^{2}$ Department of Psychiatry and Psychotherapy, Faculty of Medicine, Semmelweis University, Budapest, Hungary \\ ${ }^{3} 1$ st Department of Psychiatry, Faculty of Medicine, University of P. J. Safarik, Košice, Slovak Republic \\ ${ }^{4}$ Department of Psychiatry, North Estonia Medical Centre, Tallinn, Estonia \\ ${ }^{5}$ Department of Medical Psychology, University of Łódź, Łódź, Poland \\ ${ }^{6}$ Private Psychiatric Clinic, Odessa, Ukraine \\ ${ }^{7}$ University of Notre Dame / Marian Centre, Wembley, WA, Australia \\ ${ }^{8}$ School of Psychiatry and Clinical Neurosciences, University of Western Australia, Crawley, WA, Australia
}

received: 11.10.2016;

revised: 12.4.2017;

accepted: 3.5 .2017

\section{SUMMARY}

Though a number of reports on the use of electroconvulsive therapy (ECT) has been published from the Central-Eastern European region over the past two decades, a systematic review of this literature has not been published. Thus the aim of this paper was to review recent trends in ECT practice in Central-Eastern Europe. Systematic literature search was undertaken using the Medline, PSYCHINFO and EMBASE databases covering the period between January 2000 and December 2013. Relevant publications were found from the following countries: Bulgaria, Croatia, Czech Republic, Estonia, Hungary, Latvia, Lithuania, Poland, Romania, Serbia, Slovakia, Ukraine, but none from Albania and Moldova. ECT practice in the region shows a heterogeneous picture in terms of utilization rate, main indications, and the technical parameters of application. On one end of the spectrum is Slovakia where the majority of psychiatric facilities offer ECT, on the other end is Slovenia, where ECT is banned. In about half of the countries schizophrenia is the main indication for ECT. In Ukraine, unmodified ECT is still in use. Clinical training is generally lacking in the region and only 3 countries have a national ECT protocol. Possible ways of improving ECT practice in the region are briefly discussed.

Key words: ECT - Central-Eastern Europe - affective disorders - schizophrenia - training

\section{INTRODUCTION}

Convulsive therapy for the treatment of severe psychiatric disorders has been introduced in psychiatry in Central-Eastern Europe, namely in Budapest, Hungary in 1934 (Meduna 1935). In the subsequent years, the new method has rapidly spread in Europe and the United States and later all over the world (Fink 2001). As chemical seizure induction was unpredictable and anxiety-provoking, a new method, electric seizure induction, was pioneered in Rome in 1938 (Bini 1938).

While the exact date and place of the use of first convulsive therapy in different Central-Eastern European countries cannot be traced, the first scientific reports apart from Meduna's contributions (Meduna 1937) were published from this region in the early 1940s (Matulay \& Skotnický 1941, Vaičiūnas 1943). The wider use of convulsive therapies in Europe was hindered by World War II (WWII).

In the years following WWII, the political and ideological climate had a decisive impact on psychiatry in general and convulsive therapy in particular in communist Central-Eastern Europe. In 1952, a clearly politically-driven directive was issued in the Soviet
Union to "immediately restrict indications" of convulsive therapy, because of its Western origin, essentially banning ECT for more than a decade there (Nelson \& Giagou 2009). This directive might have influenced national ECT practices in some, but not all communist countries; the use of ECT actually increased in Hungary during the 1950s (Gazdag et al. 2007).

Throughout the period of the Cold War (1950-1989), access to scientific information from the Western world was severely restricted in Central-Eastern Europe. In the second half of the $1980 \mathrm{~s}$, the communist regimes entered a deep economic and political crisis that eventually resulted in the dissolution of the Soviet Unionbacked political systems in Central-Eastern Europe by the early 1990s. Over the past 25 years access to new scientific information and participation in scientific events organized all over the world has become much easier for the Central-Eastern European professional community, although economical hindrances still exist.

Though increasing number of reports on the use of ECT were published from this region in the 2000s, Central-Eastern Europe was overlooked in a recently published monograph (Swartz 2009), and only a small segment of this literature was included in a recent 
exhaustive worldwide overview of ECT practice (Leiknes et al. 2012). Thus, the aim of this paper was to review recent trends in ECT practice in Central-Eastern Europe.

\section{METHODS}

A systematic literature search was undertaken including the Medline, PSYCHINFO and EMBASE databases covering the period between January 2000 and December 2013. Search terms entered included "electroconvulsive therapy," "ECT," combined with all of the following: "use," "utilization," "practice," "survey," and any of the names of countries in Central-Eastern Europe. Relevant references known to the authors of this review or reference lists in retrieved papers were also included. Publications in any languages were considered.

\section{RESULTS}

Relevant publications were found from the following countries: Bulgaria (Hranov et al. 2012), Croatia (Kuzman et al. 2014), Czech Republic (Köhler 2012), Estonia, Latvia, Lithuania (Lõokene et al. 2014), Hungary (Gazdag et al. 2004a,b, Gazdag et al. 2013), Poland (Palinska et al. 2008, Gazdag et al. 2009), Romania (Gazdag et al. 2011), Serbia (Spiric et al. 2014), Slovakia (Dragasek 2012), Ukraine (Olekseev et al. 2014), but none from Albania or Moldova.

The number of ECT centers and rates of ECT-treated patients and the number of psychiatric facilities are presented in Table 1. The most important technical data of ECT administration are summarized in Table 2.

Table 1. Number of ECT centers and rate of ECT-treated inpatients against the background of the number of psychiatric facilities and the whole population

\begin{tabular}{lrccc} 
& Population & $\begin{array}{c}\text { No. psychiatric } \\
\text { facilities* }\end{array}$ & No. ECT centers & $\begin{array}{c}\text { Rate of ECT treated patients } \\
\text { (per 10.000 population) }\end{array}$ \\
\hline Hungary (2002) & 10.0 million & 76 & $34(44.7 \%)$ & 0.31 \\
Poland (2005) & 38.6 million & 58 & $25(43.1 \%)$ & 0.11 \\
Slovakia (2008-10) & 5.4 million & 36 & $33(91.6 \%)$ & 2.92 \\
Czech Republic (2010-11) & 10.5 million & 42 & $28(66.7 \%)$ & 1.36 \\
Bulgaria (2010) & 7.3 million & 33 & $4(12.1 \%)$ & 0.16 \\
Estonia (2010) & 1.3 million & 11 & $5(45.4 \%)$ & 2.78 \\
Latvia (2010) & 2.0 million & 6 & $2(33.3 \%)$ & 0.05 \\
Lithuania (2010) & 3.2 million & 10 & $5(50 \%)$ & 0.38 \\
Ukraine (2011) & 45.5 million & 146 & $8(5.5 \%)$ & 0.02 \\
Serbia (2012) & 7.2 million & 46 & $1(2.2 \%)$ & 0.08 \\
Croatia (2012-13) & 4.3 million & 29 & $3(10.3 \%)$ & 0.13 \\
\hline
\end{tabular}

* Psychiatric facilities include all public and private hospitals as well as academic centers that provide acute psychiatric service

Table 2. The most important technical parameters of ECT practice in Central-Eastern Europe

\begin{tabular}{|c|c|c|c|c|c|}
\hline & $\begin{array}{l}\text { Rate of centers } \\
\text { using square } \\
\text { wave machines }\end{array}$ & $\begin{array}{l}\text { Most common } \\
\text { electrode position }\end{array}$ & $\begin{array}{l}\text { Main indication of } \\
\text { ECT }\end{array}$ & $\begin{array}{l}\text { Rate of centers } \\
\text { offering cECT or } \\
\text { mECT }\end{array}$ & $\begin{array}{l}\text { National } \\
\text { protocol exist }\end{array}$ \\
\hline $\begin{array}{l}\text { Hungary } \\
(2002)\end{array}$ & $48 \%$ & $\begin{array}{l}\text { bifrontal } \\
\text { bifronto-temporal }\end{array}$ & schizophrenia & $0 \%$ & yes \\
\hline Poland (2005) & $70 \%$ & bitemporal & affective disorders & $25 \%$ & no \\
\hline $\begin{array}{l}\text { Slovakia } \\
(2008-10)\end{array}$ & $50 \%$ & $\begin{array}{l}\text { bitemporal } \\
\text { bifronto-temporal }\end{array}$ & affective disorders & $6.3 \%$ & no \\
\hline $\begin{array}{l}\text { Czech Republic } \\
(2010-11)\end{array}$ & $100 \%$ & $\begin{array}{l}\text { bifronto-temporal } \\
\text { bifrontal }\end{array}$ & schizophrenia & $12 \%$ & yes \\
\hline $\begin{array}{l}\text { Bulgaria } \\
(2010)\end{array}$ & $75 \%$ & $\begin{array}{l}\text { bifrontal } \\
\text { bitemporal }\end{array}$ & affective disorders & $50 \%$ & no \\
\hline $\begin{array}{l}\text { Estonia } \\
(2010)\end{array}$ & $100 \%$ & $\begin{array}{l}\text { bitemporal } \\
\text { right unilateral }\end{array}$ & schizophrenia & $80 \%$ & no \\
\hline Latvia (2010) & $0 \%$ & no information & catatonia & $0 \%$ & yes \\
\hline Lithuania (2010) & $75 \%$ & bitemporal & schizophrenia & $0 \%$ & no \\
\hline $\begin{array}{l}\text { Ukraine } \\
\text { (2011) }\end{array}$ & $60 \%$ & $\begin{array}{l}\text { bitemporal } \\
\text { unilateral }\end{array}$ & affective disorders & $40 \%$ & no \\
\hline Serbia (2012) & $100 \%$ & bifrontal & affective disorders & $100 \%$ & no \\
\hline Croatia (2012-13) & $100 \%$ & bifrontal & schizophrenia & $33 \%$ & no \\
\hline
\end{tabular}

$\mathrm{cECT}=$ continuation electroconvulsive therapy; $\mathrm{mECT}=$ maintenance electroconvulsive therapy 


\section{DISCUSSION}

ECT practice of the Central-Eastern European countries is heterogeneous in terms of utilization rate, main indications, and the technical parameters of application. On one end of the spectrum are Slovakia and the Czech Republic where the majority of the psychiatric facilities offer ECT $(92$ and $67 \%$, respectively) for a significant number of patients $(2.92$ and 1.36 per 10,000 population, respectively). Also a high rate of patients $(>2 / 10,000$ population) are treated with ECT in Estonia, but in a somewhat more centralized form, as only less than $50 \%$ of the psychiatric facilities provide ECT. The advantage of this centralization is that all centers use modern, square-wave machines and experienced teams are administering ECT. Similarly high utilization rates are characteristic for some Western-European (e.g. Belgium (Sienaert et al. 2006), the UK (Benbow \& Bolwig 2009) and Scandinavian countries (Benbow \& Bolwig 2009). Medium utilization rates of ECT are characteristic of Hungary and Lithuania with figures between 2 and 0.2 per 10,000 population, respectively and with $50 \%$ of psychiatric facilities offering ECT. Similar figures were reported from Spain (BertolinGuillen et al. 2006). The rate of ECT treated patients remains below $0.2 / 10,000$ population in the rest of the region. This extremely low utilization rate found in the central and eastern part of Europe, is not exceptional in other parts of the world, for instance in Hong-Kong (Chung 2003).

Poland has relatively high number of ECT centers (43\%), but the rate of facilities providing ECT is low in all other countries. In Ukraine, Croatia, and Serbia, both the rate of treated patients and that of the ECT centers are so low that access to ECT is problematic both from clinical and ethical viewpoints. The other end of the spectrum is occupied by Slovenia, the only country in the region where ECT has been banned since 1994 (Eranti \& McLoughlin 2003). Slovenian patients who need ECT are transferred to the neighboring countries for ECT (Oral et al. 2008).

Bilateral, usually bifrontal or bifrontotemporal, electrode position is still characteristic in the CentralEastern European region. Unilateral position as a second option is mentioned only in Estonia and Ukraine (Lõokene et al. 2014, Olekseev et al. 2014).

The clinical indications for ECT also show a heterogeneous picture. In nearly half of the countries, schizophrenia remains the main indication while affective disorders predominate in the other half (Table 2). No correlation appeared between the frequency of use and indications. For example, Estonia has a high utilization rate and schizophrenia as a first indication, while in Ukraine and Serbia affective disorders are the first indication but the utilization rates are very low. Lack of comprehensive national guidelines and training could be the main reasons for these practices.
The lack of centrally organized ECT training or courses are shared characteristic of all countries in the region. Teaching the theoretical basis of ECT is not part of the regular medical curricula, except for Croatia and Ukraine, while practical experience is not provided in any country. The theoretical principles of ECT are taught in every residency programs of the region, but without supervised practical sessions. A frequently used way of distributing knowledge on ECT is via CME courses, for instance in Hungary and Serbia. In a significant number of countries like Bulgaria, Hungary, Poland, Serbia, Ukraine, textbooks or chapters on ECT in monographs have been published in local languages in the last decades (Merdzhanov 1985, Bánki 2009, Krzyżanowski 1991, Maric and Jasovic-Gasic 2010, Maruta et al. 2012).

Several difficulties hindering wider ECT use have been reported in the literature. Most frequently mentioned problems include the lack of anesthesiologists and the necessary technical equipments. This factor might have contributed to the use of unmodified ECT in Ukraine (Olekseev et al. 2014), while this long outdated practice was not reported from any other country of the region. Lack of separate financing for ECT services was also mentioned as a reason for low utilization in some publications (Hranov et al. 2012, Gazdag et al. 2012). Differences in financing might also be responsible for the extreme (minimum 50-fold) difference detected between rates of ECT use in public hospitals and the only private hospital in Ukraine (Olekseev et al. 2014).

While in a worldwide review (Leiknes et al. 2012) professional attitudes towards ECT was reported to be generally favorable, this is generally not true for the Central-Eastern European countries. In comparison with the results of attitude surveys in the literature, significantly less favorable attitudes were detected in a Hungarian survey (Gazdag et al. 2004b) and the results were even worse in a Romania (Gazdag et al. 2011). Although no structured large-scale public attitude survey have been published, some papers (Hranov et al. 2012, Spiric et al. 2014) listed unfavorable public attitudes among the reasons for low utilization rates.

The trend of ECT use in Central-Eastern European countries is varied. In some countries ECT use is still increasing, e.g. in Poland and Lithuania. In Poland the number of centers providing maintenance ECT is also increased. For some countries a high and steady use is characteristic. Slovakia and Estonia are two typical examples. Low and stagnant state use is characteristic of Bulgaria, Serbia and Croatia. A decreasing tendency of ECT use is observed in Hungary and Latvia.

\section{CONCLUSIONS}

There are several aspects of ECT practice in the region that should be improved. The most urgent task is the elimination of unmodified ECT, followed by the publication of national protocols in each country. 
Teaching ECT in medical curricula and provision of supervised clinical practice in residency training are also important targets for improving ECT practice. The quality of ECT provision could be improved with the development of treatment standards that would form a complete accreditation system for the whole region like the ECT Accreditation Service (ECTAS) within the Royal College of Psychiatrists (Benbow \& Bolwig 2009). These steps may enhance the quality of ECT practice leading to a more positive attitude towards ECT in both the professional and the lay community.

\section{Acknowledgements: None.}

\section{Conflict of interest: None to declare.}

\section{Contribution of individual authors:}

\section{Gábor Gazdag \& Gabor S. Ungvari: designed the} study;

Gábor Gazdag \& Rozália Takács: performed the literature search;

Gábor Gazdag, Jozef Dragasek, Margus Lõokene, Tomasz Sobow, Aleksey Olekseev \& Gabor S. Ungvari: participated in the analysis and interpretation of the data;

Rozália Takács: prepared the first draft of the manuscript.

\section{References}

1. Bánki MCs: Elektrokonvulziv kezelés (electroconvulsive therapy). In Füredi J, Németh A \& Tariska P (eds): A Pszichiátria Magyar Kézikönyve (Hungarian Handbook of Psychiatry), 490-7. Medicina, 2009.

2. Benbow SM \& Bolwig TG: Electroconvulsive therapy in Scandinavia and the United Kingdom. In: Swartz CM (ed): Electroconvulsive and Neuromodulation Therapies, 236-45. Cambridge University Press, 2009.

3. Bertolin-Guillen JM, Peiro-Moreno $S \&$ \& Hernandez-dePablo ME: Patterns of electroconvulsive therapy use in Spain. Eur Psychiatry 2006; 21:463-70.

4. Bini L: Experimental researches on epileptic attacks induced by the electric current. The treatment of schizophrenia: insulin shock, cardiozol, sleep treatment. Am J Psychiatry 1938; 94(Suppl):172-4.

5. Chung KF: Electroconvulsive therapy in Hong Kong: rates of use, indications, and outcome. J ECT 2003; 19:98-102.

6. Dragasek J: Electroconvulsive Therapy in Slovakia. J ECT 2012; 28:p e7-e8.

7. Eranti $S$ \& McLoughlin D: Electroconvulsive therapy state of the art. Br J Psychiat 2003; 182:8-9.

8. Fink M: Convulsive therapy: a review of the first 55 years. $J$ Affect Disord 2001; 63:1-15.

9. Gazdag G, Baran B, Bitter I, Ungvari GS \& Gerevich J: Regressive and intensive methods of electroconvulsive therapy: a brief historical note. J ECT 2007; 23:229-32.

10. Gazdag G, Kocsis $N$ \& Lipcsey A: Rates of electroconvulsive therapy use in Hungary in 2002. J ECT 2004; 20:42-4.
11. Gazdag G, Kocsis N, Tolna J \& Lipcsey A: Attitudes towards electroconvulsive therapy among Hungarian psychiatrists. J ECT 2004; 20:204-7.

12. Gazdag G, Palinska D, Kloszewska I \& Sobow T: Electroconvulsive therapy practice in Poland. J ECT 2009; 25:34-8.

13. Gazdag G, Takács R, Tolna J, Iványi Z, Ungvari GS \& Bitter I: Electroconvulsive therapy in a Hungarian academic centre (1999-2010). Psychiatr Danub 2013; 25:366-70.

14. Gazdag G, Zsargó E, Kerti KM \& Grecu IG: Attitudes toward electroconvulsive therapy in Romanian psychiatrists. J ECT 2011; 27:e55-6.

15. Hranov LG, Hranov $G$, Ungvari GS \& Gazdag G: Electroconvulsive therapy in Bulgaria: a snapshot of past and present. J ECT 2012; 28:108-10.

16. Köhler R: Současná praxe v provádèni elektrokonvulzivni terapie $v$ České republice. (Current practice of electroconvulsive therapy in the Czech Republic). Psychiatrie 2012; 16(Suppl 1):p44.

17. Krzyżanowski J: Leczenie Elektrowstrzasami (Electroconvulsive therapy). LogoScript Sp. z o.o., Warszawa, 1991.

18. Kuzman MR, Pranjkovic T, Degmecic D, Lasic D, Medic $A \&$ Gazdag G: Electroconvulsive therapy in Croatia. $J$ ECT 2014; 30:42-3.

19. Leiknes KA, Jarosh-von Schweder L \& Høie B: Contemporary use and practice of electroconvulsive therapy worldwide. Brain Behav 2012; 2:283-344.

20. Lõokene M, Kisuro A, Mačiulis V, Banaitis V, Ungvari GS \& Gazdag G: Use of electroconvulsive therapy in the Baltic states. World J Biol Psychiatry 2014; 15:419-24.

21. Maric $N$ \& Jasovic-Gasic M: Elektrokonvulzivna terapija (Electroconvulsive therapy). In: Jasovic-Gasic M \& LecicTosevski D (eds): Psihijatrija (Psychiatry), 277-8. Libro Medicorum, 2010.

22. Maruta NA, Pidkoritov VS, Pavlov AY, Harchenko AV \& Serikova OI: Treating Mental Illness with Electroconvulsive Therapy: Methodical Recommendations. Kharkov: National Academy of Medical Sciences (in Ukrainian), 2012.

23. Matulay K \& Skotnický J: Liečenie duševných chorôb elektrickým šokom. (Treatment of mental disorders with electric shocks). Slovenský lekár 1941; 3:1-5.

24. Meduna L: Versuche über die biologische Beeinflussung des Ablaufes der Schizophrenie. Z ges Neurol Psychiatr 1935; 152:234-62.

25. Meduna L: Die Konvulsionstherapie der Schizophrenie. Halle: Carl Marhold Verlagsbuchhandlung, 1937.

26. Merdzhanov Ch: Electroconvulsive Therapy. Medizina $i$ Fizkultura (in Bulgarian), Sofia, 1985.

27. Nelson AI \& Giagou N: History of electroconvulsive therapy in the Russian Federation. In: Swartz CM (ed): Electroconvulsive and Neuromodulation Therapies, 26675. Cambridge University Press, 2009.

28. Olekseev A, Ungvari GS \& Gazdag G: Electroconvulsive therapy practice in Ukraine. J ECT 2014; 30:216-9.

29. Oral ET, Tomruk N, Plesnicar BK, Hotujac L, Kocmur M, Koychev $G$ et al.: Electroconvulsive therapy in psychiatric practice: a selective review of the evidence. Neuroendocrinology Letters 2008; 29(Suppl 1):17-36.

30. Palińska D, Gazdag G, Sobów T, Hese RT \& Kłoszewska I: Leczenie elektrowstrzasowe $w$ Polscew 2005 roku Wyniki ankiety przeprowadzonej $w$ polskich szpitalach 
psychiatrycznych (Electroconvulsive therapy in Poland in 2005-a nationwide questionnaire study performed in Polish psychiatric clinics). Psychiatria Polska 2008; 42:825-39.

31. Sienaert P, Dierick M, Degraeve G\& Peuskens J: Electroconvulsive therapy in Belgium: a nationwide survey on the practice of electroconvulsive therapy. $J$ Affect Disord 2006; 90:67-71.
32. Spiric Z, Stojanovic Z, Samardzic R, Milovanović $S$, Gazdag $G$ \& Marić NP: Electroconvulsive therapy practice in Serbia today. Psychiatr Danub 2014; 26:66-9.

33. Swartz CM: Electroconvulsive and Neuromodulation Therapies. Cambridge University Press, New York, 2009.

34. Vaičiūnas $V$ : Psichiniu ligoniu gydymas (treatment of mentally ill patients). Lietuviškoji medicina 1943; 23:6-21.

\section{Correspondence:}

Gábor Gazdag, MD, PhD

Centre for Psychiatry and Addiction Medicine

Szt. István and Szt. László Hospitals

Budapest, Gyáli út 17-19. 1097 Hungary

E-mail: gazdag@lamb.hu 